\title{
Mutirão in cob houses building process: advantages and limitations
}

\author{
Juliano Moreira Coimbra ${ }^{1, a}$ \\ ${ }^{1}$ Universidade Federal de Pelotas, Faculdade de Arquitetura e Urbanismo, 1359 Benjamin Constant, Pelotas, Brasil.
}

\begin{abstract}
Building with earth is an age-old practice still common in many cultures of the world, especially where there is less presence of industrialization. In recent decades, there has been a growing interest in incorporating more sustainable processes in the production of consumer goods in all spheres (environmental, economic and social). In construction, one of the emerging alternatives is natural building, wich proposes the use of natural materials - such as clay, wood, straw and stone - and traditional building techniques, with simple resources that are accessible to most people, hence the association with self-construction and mutirão - Portuguese word for collective mobilization for mutual assistance in a free character. The problem addressed is the feasibility of mutirão and its social gains in natural building that has mud as key material. The object of study is the earthen house of the author, designed and self-built in the rural area of Pelotas-RS, southern Brazil. The general objective is to study the possible gains of the mutirão practice in the refered natural building, on wich more than 80 volunteers helped. The specific objectives are: a) to define the concept of natural construction and to explain the constructive technique applied in the house studied (cob); b) to analyse the relationship between mutirão and complexity of the constructive technique; and c) evaluation of the observed social sustainability gains. As results, it is noticed that the mutirão sessions attracted many helpers due to the curiosity about learning an unconventional constructive technique and allowed many exchanges of ideas and experiences. They have also contributed to a more playful work environment, despite the considerable amount of work produced, considering the inexperience of the volunteers. It is concluded that natural building and mutirão complete each other, and can collaborate for practical gains of social sustainability.
\end{abstract}

Keywords. Architecture, natural building, social sustainability, mutirão, self-building.

\section{Introduction}

Earth still is the most available building material in the world. It is estimated that a third of the world population live in houses made out of mud. In developing countries the number can reach to fifty percent (MINKE 2002). The Industrial Revolution, since the late sevententh century, drasticaly afected how, where and with wich materials the houses of "ordinary" people would be built. Beginning in the United Kingdom, the vernacular practice lost importance before housing mass production. Today one can see a detachment of society from the vernacular techniques, as the whole social structure suffered several changes as well, making the once popular self-construction almost fully desapear among those living in the industrialized world. Consulted works (WEISMANN and BRYCE 2006; EVANS 2002) aim this social reshape as responsable for the association of earth buildings to poverty, as it is taken as an inferior material.

Such situation motivated people to pursuit alternatives. In the "back-to-the-land" moviments of the 1960 s and the 1970s there was a new interest on studying and put into practice natural building

\footnotetext{
a Corresponding author: julianomcoimbra@hotmail.com
}

techniques. At the energy crisis of the 1970s, many public atention was directed due to a propper use of natural ressources, building energy efficience, passiv house and alternative means of energy (EVANS 2002).

\section{Self-construction and mutirão}

Historically, in most cultures, to build the own house used to be a comon practice. If the work was to heavy or became too slow, the family would gather to help. The idea of trading this duty to people outside the friends or family circle is recent in human history. This resulted in people working decades to pay for a house they are not directly connected with (EVANS 2002).

This disconnection is also noticed by Alexander et al. (1977), in the book A pattern language. The authors defend that modern types of property such as renting, when the dweller is not the legally owner, are opposite to natural processes of formation of stable communities and do not allow people to feel trully comfortble since the house does not belong to them. Enphasyzing the definition of ownership controll - instead of ownership as financial investiment - , the authors believe that 
people would only feel comfortable in their houses if they could adapt them according to their needs, and such investiments could only happen if they were the legally owners of the building (ALEXANDER et al. 1977).

In Brazil, as shows Bonduki (2011), the idea of the small private land was largely spread between the 1930s and the 1940s. However, that specially contributed to a wide peripherical occupation in the cities by the poorer population that moved to low cost land, away from urban facilities, to self-build their substandard housing, once they could not have access to the limited housing programs offered by the government.

One can therefore see that self-building and mutirão - popular word in Brazilian Portuguese for a collective mobilization for mutual assistance with a free character - to Brazilian population in general is associated with lack of ressources, poverty and precariousness. But the retake of these practices since the "back-to-the-land" moviments from the 1960s introduces a new approach to the problem: "The natural building movement has helped humans reconnect with our tradition of self-reliant shelter, surely one of our natural rights" (EVANS 2002, p. 5). This way, people interested in living more connected to the natural environment and to each other have begun to appropriate traditional building techniques and natural materials to build themselves their houses.

What one intends to demonstrate in this paper is the good reception of mutirões - plural for mutirão - in natural buildings that use earthen techniques for walls, such as cob, to be explained later. To Minke (2002), cobbuilding techniques does not need people experienced in building nor demand complex tools and heavy machinery. At the same time, they are more laborous to work with and is recommended at least one experienced person in the construction site to control the process and teach the team.

\section{Natural building and cob}

\subsection{Defining natural building}

It is common to think about natural building (or "bioconstruction", neologism often used in Brazilian context) as a building built with natural materials, that is, non-industrialized (Figure 1). However, any rowmaterial to build a house, despite its roughness would demand a certain level of processing. One understands, in this kind of work, natural materials as "materials that, even when processed, retain its natural essence" (EVANS 2002, p.14). It means that a tree, even when chopped into timber sheets, keeps its natural aspects and proprieties. Industrialized timber, such as OBS or MDF, drastically modify the proprieties of the original material, turning it into a new one, that cannot be no longer considered natural.

Still, as the consulted bibliography shows, the concept of natural building is wider - to Evans (2002), natural building goes beyond materials - implies in completely different atitudes adressed to site plan, ecology, work force, and use of the building. It is to pay more attention to the natural structures that coordenate the world and transport them to the work.

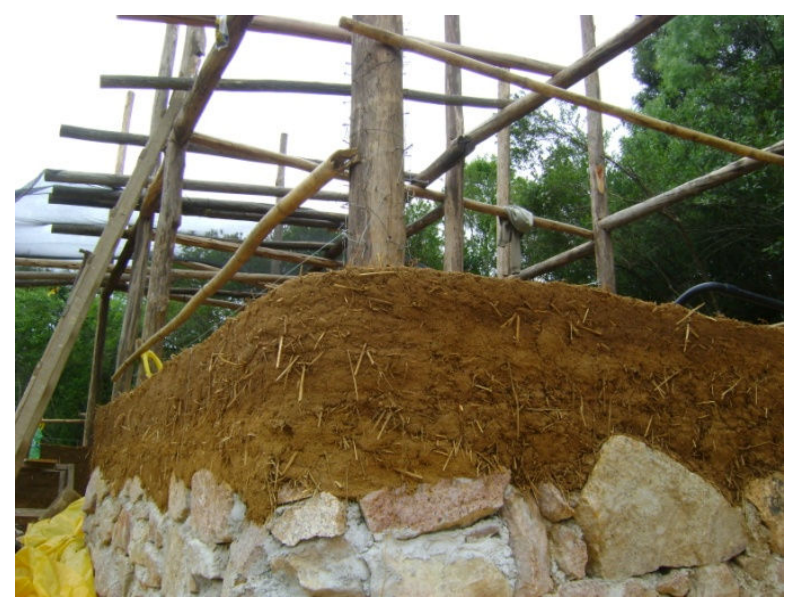

Figure 1. Stone, mud and wood are examples of natural materials. Detail of a rounded cob wall corner of the studied house. From the author.

To Weismann and Bryce (2006), more than building with what, is to ask yourself how, where and why to build. They highlight as natural building basic concepts: a) an enphasis on the minimisation of the environmental impact of materials, techniques and the building itself; $b$ ) simple low-tech approach; c) use of local, renewable and available resources; d) a respect with the building site and its local environment as an unique place; e) encouragement to self-construction; f) priority to materials that have not been industrially processed, such as stone, mud, straw and wood. Also here the materials are not only important, but also a single component in a whole wider context.

In this paper, thus, one defines natural building as a practice that aims to employ only the minimum necessary of industialized processes and materials and is characterized, formal and technicaly, by the presence of natural materials and low technology building techniques.

\subsection{Cob walls made out of mud}

Minke (2002) points out three disadvantages that mud has in comparison to the most common industrialized materials: a) it is not a standardized material, it can vary its characteristics from place to place; b) it contracts when drying, and may present cracks; c) it is not impermeable, and should always be protected from the direct action of rain. Nevertheless, this natural material has several advantages when compared to industrialized materials: it regulates the humidity of the environment, stores heat, is produced with low energy expenditure, it is reusable, it is economical, suitable for selfconstruction, it preserves organic materials when in direct contact (like when it is covering wood), among other benefits.

Even the mentioned disadvantages do not discredit the use of the material. The variation of soil characteristics from different places can be compensated with the addition of more sandy or clayey soil, followed by simple tests that guarantee the reliability of the 
adopted trait; cracks that may appear, feared to be able to house insects like the "barber", causing the Chagas disease, are easily eliminated by towing the wall; and the same plaster, added to generous eaves, will guarantee protection against the direct incidence of the rain (MINKE 2002).

Thus, one of the most recurring materials in natural construction is earth, or more specifically, mud. It is possible to make walls, niches, benches and other architectural elements out of mud, according to the chosen technique, that can be adobe, rammed earth paua-pique, cob, among others (VAN LENGEN 2009; MINKE 2002). In the house studied in this work the main technique used for the walls was cob.

Cob is an English term for a building technique building with mud that does not need shapes, bricks or wooden structure. The vernacular tradition of the English cob house dates from the thirteenth century to the industrial era. Nevertheless, the same technique or similar variations can be found in practically all the continents (EVANS 2002).

The constitution of the cob is based on four materials: clay soil, aggregate (sand), fresh straw and water. Sand and clay should be mixed in the ratio of $3: 1$. Therefore, sand is the most abundant ingredient, and the final trait should result in a homogeneous mass balanced, that does not shed (excess sand) and is not sticky (excess clay) (LENGEN 2008).

In cob, mud is seated with barehands, without need of forms, complementary structures or mortar (Figure 2). The walls of the house are raised in layers (rows) of approximately $30 \mathrm{~cm}$ at a time. When completing the first row, you can start a new one, saving at least one day for the lower row to dry. Thus, the walls of the house are raised and dried as a single whole, working as a monolithic structure (EVANS 2002; WEISMANN and BRYCE 2006).

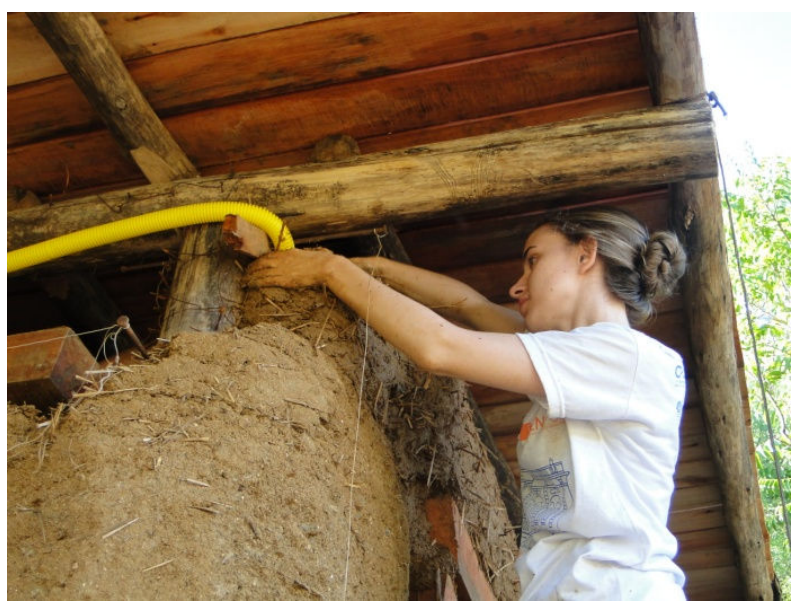

Figure 2. Cob walls are thick mud walls sculpted with barehands, without any need of surplus structure. From the author.

The cob wall is like a common brick masonry in small scale: the particles of sand are like bricks; clay, in contact with water, has its binder properties activated and becomes the mortar of settlement; finally, straw is added as a fibrous material to help the sand in the function of stabilizing the clay, preventing eventual cracks when drying (MINKE 2002).

Compared with conventional bricks, cob has much less embodyed energy in its production, since it uses raw clay, and is not burned in wood-fired ovens. Compared to other natural construction techniques, it has the advantage of no need of shapes (such as in adobe or rammed-earth) and no need of structure for the mud to grasp to (as the bamboos in Brazilian pau-a-pique). On the other hand, cob walls require a great thickness to stabilize (around $35 \mathrm{~cm}$ minimum), which can be considered a problem due to the volume of material used, but could also be advantageous considering that the wall will have a larger termal mass (it will store the heat for longer time, differentiating outside and inside temperatures).

The two main precautions when working with cob are the direct action of rain and the use of portland cement in the plaster. Earth is not waterproof and can lose a lot of resistance when wet again. It is advisable to raise the walls of the ground with a stone foundation and to design roofs with generous eaves (between $45 \mathrm{~cm}$ and $60 \mathrm{~cm}$ ). In addition, to ensure greater safety, it is recommended to protect the external walls with limebased plaster. Lime is a porous material and allows the wall to breathe and balance its moisture with ambient air, besides its good water resistance properties (WEISMANN and BRYCE 2006). Cement should not be used when towing mud walls because, although it is more impermeable than lime, it does not have the porosity that clay requires for the wall to "breathe". Cement and clay do not work well together, and with the appearance of the first cracks, water can enter, can not escape from the wall by evaporation, and moisture will accumulate at the base of the wall, where are the largest loads, and may cause collapse in the structure (EVANS 2002).

\section{Case study - our cob cottage}

\subsection{Project}

As object of study, the author presents the cob house he himself made to live, as soon as he graduated in Architecture and Urban Design. The design was made in the first half of 2014 and the work started in August of that year, going up to August 2015. The site is a small rural property in the countryside of Pelotas, Rio Grande do Sul, southernmost Brazil. An extremely narrow site (ranging from $12 \mathrm{~m}$ to $50 \mathrm{~m}$ wide by approximately 320 $\mathrm{m}$ long), with a hectare of area, not cultivated for more than two decades, taken by a young bush, with a total slope of $18 \mathrm{~m}$ towards the bottom, where a stream runs.

The main conditioning that defined the implantation of the house were ground unevenness, solar trajectory and visual interest. It was chosen an implantation to the center of the lot, which would guarantee both privacy and proximity to the stream and beautiful visuals of the rural landscape, as well. The gaps up to $1.5 \mathrm{~m}$ between 
the ends of the building were minimized by level differences between rooms.

The house has built area of $82.56 \mathrm{sqm}-52.80 \mathrm{sqm}$ of internal area, $6.50 \mathrm{sqm}$ of porch and $22.26 \mathrm{sqm}$ of wall area, which represents $27 \%$ of the built area. That happens because the cob walls were raised $42 \mathrm{~cm}$ thick ( $37 \mathrm{~cm}$ of mud $+2.5 \mathrm{~cm}$ of lime plaster on each side), consuming a mud volume estimated at $27 \mathrm{~m}^{3}$ (almost equivalent to four loaded concrete mixer trucks).

The house has a foundation of irregular granite stones, built both to support the walls and raise them from the ground. At the ends and intersections of the foundations there are round eucalyptus pillars attached, put to structure the roof and allow it to be started before the walls were finished. In the second floor - the mezzanine - the walls are made out of wood, to make the cons walls, to facilitate the execution (raising the mud would require extra work). Both floors received green roofs, consisting of eucalyptus board base waterproofed with vinyl truck canvas.

\subsection{Team work and the mutirão sessions}

According to Minke (2002), a natural construction is much more laborious, given to its artisanal character. Thus, it was planned the strategy of mutirão sessions on Saturdays, to involve as many people as possible and make better use of time and tasks. However, at the begining of the foundations, one realized that not all steps would be suitable for inexperienced volunteers, either for being physically heavy tasks, either for requiring some specific technical knowledge.

The execution of the house was taken by a three-tofive men team working five days a week full time - the regular staff — with eventual additional construction professionals assistance - carpenters, plumbers, electritians and masons. The author, owner and architect of the house - within no practice in natural construction yet, only theoretical studies —-worked as a builder and coordinated a team of young people with little or no experience in conventional building, much less in natural building. In Table 1, it is possible to see the different steps of the work and the corresponding type of workmanship, professional or voluntary.

Table 1. Steps of the work.

\begin{tabular}{cccc} 
Steps & $\begin{array}{c}\text { Professional } \\
\text { Workforce }\end{array}$ & Mutirão \\
\hline 1 & Foundations & No & No \\
\hline 2 & Timber structure & Yes (carpenters) & No \\
\hline $\mathbf{3}$ & Walls (cob) & No & Yes \\
\hline $\mathbf{4}$ & Roof & No & Yes \\
\hline 5 & Plasters & Yes (mason) & No \\
\hline 6 & $\begin{array}{c}\text { Electric and } \\
\text { hydrosanitary } \\
\text { installations }\end{array}$ & $\begin{array}{c}\text { Yes (plumber } \\
\text { and electrician) }\end{array}$ & No \\
\hline 7 & $\begin{array}{c}\text { Floors and finishes } \\
\text { Yes (mason) }\end{array}$ & No
\end{tabular}

The foundations did not require professionals because they were technically uncomplicated, though very physically draining to perform. In the next step, woodwork, it was contracted a team of professional carpenters. Only in the begining of the cob walls, at the end of the fourth month, the mutirão strategy could happen (Figure 3).

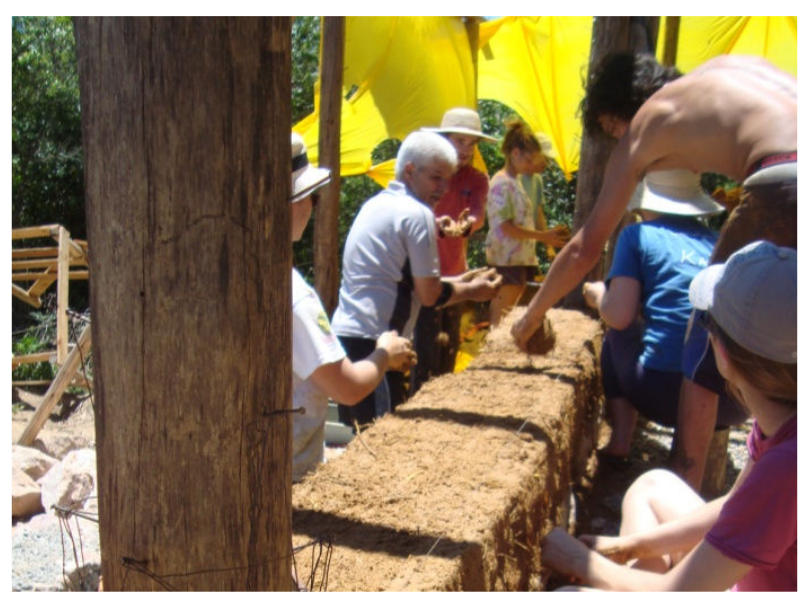

Figure 3. Volunteers raising a cob wall in the second mutirão. From the author.

The mutirão sessions took a workshop shape. There were invitations published in social media, with the dates, times and schedule: leave the city at $5 \mathrm{am}$; work from 6 am to $1 \mathrm{pm}$, with two breaks for snacks; (offered by the organization, but prepared by one volunteer) and bath in the stream in the afternoon. There were also rides for those unable to travel to the site of the work by themselves, as the house is $37 \mathrm{~km}$ from downtown Pelotas.

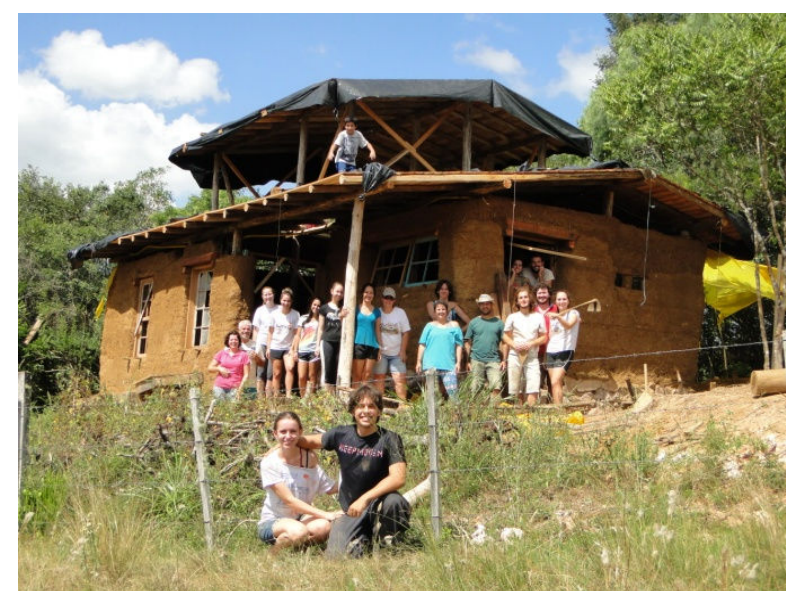

Figure 4. At the thirteenth mutirão, cob walls were almost finished. From the author.

The mutirões followed simple dynamic: the author, who worked as builder with the regular staff during the week, would assume the task of facilitating, helping people to build. In addition to questions about the work, many conversations arose about the reasons for choosing this type of construction, advantages and disadvantages, the option to live in the countryside, etc. Eventually there were also multidisciplinary exchanges among the volunteers, many of them related to building and construction area, research and academia.

As for the tasks performed in the mutirões, there were five roles determined (Table 2): first, the coordination, by the architect and owner, and the 
technical support, made by regurlar staff workers. Volunteers took on some of the other tasks: most were builders; those able to perform more demanding tasks such as carrying weight were the helpers; and generally elderly or phisically limited people were the cooks.

Table 2. Types of functions for the volunteers.

\begin{tabular}{lll} 
Roles & Tasks & Carried out by \\
\hline $\begin{array}{l}\text { Coordenation } \\
\text { and teaching }\end{array}$ & $\begin{array}{l}\text { Determine tasks, } \\
\text { motivate the } \\
\text { team, clarify } \\
\text { questions }\end{array}$ & Owner-architect \\
\hline Builders & $\begin{array}{l}\text { Build the cob } \\
\text { walls }\end{array}$ & $\begin{array}{l}\text { More careful and } \\
\text { attentive people }\end{array}$ \\
\hline $\begin{array}{l}\text { Technical } \\
\text { support }\end{array}$ & $\begin{array}{l}\text { Check } \\
\text { measurements, } \\
\text { level, plumb; } \\
\text { guide the work }\end{array}$ & $\begin{array}{l}\text { Owner-architect, } \\
\text { regular staff } \\
\text { workers }\end{array}$ \\
\hline Helpers & $\begin{array}{l}\text { Bring clay and } \\
\text { tools to builders; } \\
\text { assemble } \\
\text { scaffolding }\end{array}$ & $\begin{array}{l}\text { People with better } \\
\text { fitness for heavy } \\
\text { activities }\end{array}$ \\
& $\begin{array}{l}\text { Prepare meals, } \\
\text { serve water }\end{array}$ & $\begin{array}{l}\text { Helpful people, but } \\
\text { not able to build }\end{array}$
\end{tabular}

At the wall step, the work done in the mutirões often amounted three to four regular days of work. However, many things were already prepared beforehand aiming for greater productivity in the mutirão. Also more precise tasks, such as fixing window frames on the walls or anything that required more reflection and care, were performed by the regular staff during the week.

Part of the green roof was also built by mutirão (Figure 5). It consisted in several layers: wooden boards base over the timber structure, cardboard, vinyl canvas (for waterproofing), cardboard again and sand $(2 \mathrm{~cm})$. Gravel placed along the edges work as drains, as well holes in the baseboard at the ends, to allow the water to flow. The volunteers helped to get pieces of topsoil with native grass cover ( $7 \mathrm{~cm}$ to $10 \mathrm{~cm}$ thick) from the neighboring field and raise them to the roof.

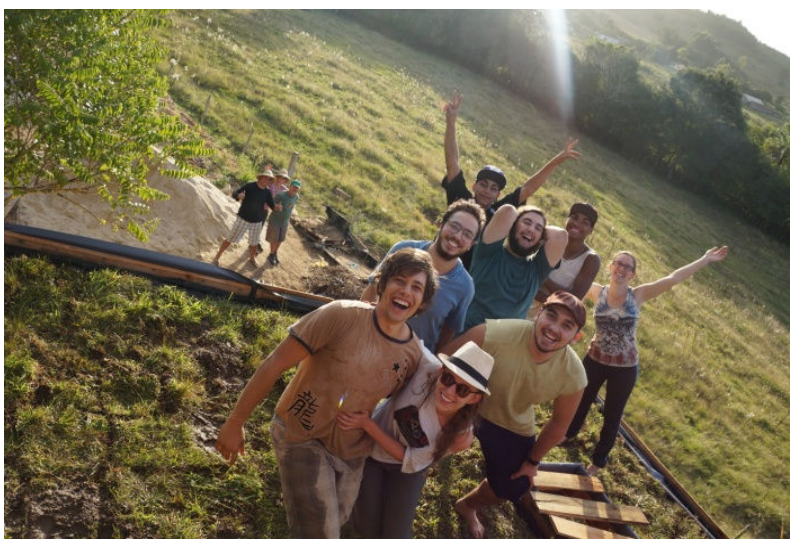

Figure 5. The last mutirão, for the green roof. The author and his wife in first plan. From the author.

In all, from November 2014, when the walls began, to April 2015, when the green roof was completed, fourteen mutirões were held, gathering 85 different volunteers. Many of them were friends, co-workers or family members, but about 25 percent of the volunteers were unknown people who found the invitation online and decided to help and share experiences.



Figure 6. The cob-timber house, a few months after mooving in. From the author.

\section{Acknowledgments}

Some conclusions emerge from the experience with mutirão in natural building. Firstly, it is questioned the "democratization" of the cob, defended by some authors referred in this paper. The main demand for labor in such buildings is to make the walls. However, other steps essential to complete the house (see Table 1) are not suitable for the help of inexperienced volunteers.

It is remarkable how easily volunteers at the building site can begin to help raise a cob wall. Yet, it is important to emphasize that the scope of construction is much larger than just the walls. Those who think of building their house with similar techniques should anticipate the cost with specialized workmanship for the other steps.

Besides the ease of learning, which allowed the expressive number of attendees (85 people in 14 mutirões), it is believed that the natural building itself and the curiosity it arouses were decisive in attracting unknow vollunteers, and would hardly happen in a conventional building - in the Brazilian context, industrialized bricks and structure in reinforced concrete, for example.

In addition to being in touch with a new technique, many volunteers have shown interest in participating to exchange ideas and information on issues beyond natural building - there were many conversations about food, education, lifestyle, and other topics related to integral sustainability, traditional lifestyle and contact with nature.

It is evident that the mutirão sessions required a lot of work: planning, disclosure, motivation, logistics (rides, meals), etc. Also during the process, there was significant effort to instruct the team, to distribute the tasks and to keep everybody motivated and comfortable. However, such an effort was offset by the considerable productivity and the resultant work environment as well, more playful and lighther, without the pressure often seen in building sites.

Finally, it is concluded that the making of cob walls in natural buildings is an appropriate task for voluntary help through mutirões, although it is a more laborious 
activity than some industrialized techniques. However, it is indicated the hiring forecast of skilled labor to other of the building that require technical experience. The mutirão in natural building is a recomended strategy due to its potential to attract people interested in the different, for offering savings, optimize the work and for collaborate with exchanges of experiences among the participants, resulting in practical gains of social sustainability.

\section{References}

ALEXANDER, C.; ISHIKAWA, S.; SILVERSTEIN, M. A pattern language. New York, Oxford University Press, 1977.

BONDUKI, N. Origens da habitação social no Brasil. 6. ed. São Paulo, Estação Liberdade, 2011.

EVANS, I. Philosophy, background and design. In: EVANS, I.; SMILEY, L.; SMITH, M. G. The handsculpted house. White River Junction, Chelsea Green Publishing, pp. 1-112, 2002.

VAN LENGEN, J. Manual do arquiteto descalço. Jandira, Empório do Livro, 2008.

MINKE, G. Manual de construcción em tierra. Montevideo, Editora Fin de Siglo, 2008.

WEISMANN, A.; BRYCE, K. Building with cob. Devon, Green Books, 2006. 